\title{
ROOT CAUSE ANALYSIS ON DEVELOPMENT OF SUSTAINABLE FISHERIES BUSINESS IN INDONESIA
}

\author{
Nimmi Zulbainarni*) and Nur Ifra Khumaera*1 \\ *) School of Business, IPB University \\ Jl. Pajajaran, Bogor, 16151, Indonesia \\ ${ }^{* *}$ Politeknik Nusantara Makassar \\ Jl. Daeng Tata Lama No.10-12 Makassar, Sulawesi Selatan, Indonesia
}

\begin{abstract}
The development of the capture fisheries sector is significant to improve the national economy, but the development of this sector needs to be regulated to create a sustainable business and ecology of capture fisheries. This study aims to examine the development of the sustainable fisheries sector in Indonesia. This research uses descriptive qualitative method by collecting data from literature studies and focus group discussions (FGD). This study was further analyzed using root cause analysis (RCA). Based on these results, the policy recommendation was obtained to realize sustainable fisheries in Indonesia. This policy recommendation also needs to be supported by government support, such as forming a fishery platform that serves as a mediator for stakeholders so that the policy that is created will positively impact the stakeholders from upstream to downstream.
\end{abstract}

Keywords: capture fisheries, strategy, sustainability, root cause analysis (RCA)

\begin{abstract}
Abstrak: Pengembangan sektor perikanan tangkap penting untuk meningkatkan perekonomian nasional namum pengembangan sektor ini perlu diatur agar tercipta keberlanjutan bisnis dan ekologi perikanan tangkap dapat tercapai. Penelitian ini bertujuan untuk mengkaji strategi pengembangan sektor perikanan tangkap di Indonesia yang berkelanjutan. penelitian ini menggunakan metode deskriptif kualitatif dengan mengumpulkan data dari studi literatur dan focus group discussion (FGD). Kajian ini selanjutnya dianalisis menggunakan root cause analysis (RCA). Berdasarkan hasil tersebut, diperoleh rekomendasi kebijakan untuk mewujudkan Perikanan berkelanjutan di Indonesia. Kebijakan ini juga perlu didukung oleh dukungan pemerintah, seperti membentuk sebuah platform perikanan yang berfungsi sebagai mediator bagi para pemangku kepentingan sehingga kebijakan yang dibuat nantinya akan berdampak positif bagi stakeholder dari hulu ke hilir.
\end{abstract}

Kata kunci: perikanan tangkap, strategi, keberlanjutan, root cause analysis (RCA)

${ }^{1}$ Corresponding author:

Email: nurifra_khumaera@yahoo.co.id 


\section{INTRODUCTION}

The capture fisheries have a significant role in national development. This sector absorbs large number of labor through fisheries activities and the processing industry. Central Bureau of Statistics (2018) Indonesia capture fisheries production in 2017 was 6,242,114 tons and the value was Rp 181,049 billion. Indonesia contributed $7.19 \%$ (6.54 million tons) world seafood production in 2016 or one level below China with 17.56 million tons (19.29\%) (FAO, 2018). Indonesia's main export commodities are tuna, squid, shrimp, and crabs. In 2017 the export value of fishery products reached USD 4,524.42. These commodities are exported to the United States, Japan, China, the European Union, ASEAN, Taiwan, South Korea, and the Middle East.

The development of the capture fisheries has a profound impact on improving the national economy. However, the development requires regulations that activities are expected not to exceed the water carrying capacity. Management of the sustainable marine and fisheries sector is an industrial system that interrelated with one another. Capture fisheries is a system that fish, fisherman, fishing gear, vessel, and ports are the subsystems in an industry. Increased fisheries production reflects an increase in economic aspects. Fisheries' productivity should be in accordance with the environmental carrying capacity and economic aspects that reflected through profitable business achievements, social aspects through fisherman welfare guarantees, and ecological aspects through regulating the number of production inputs that appropriate with the carrying capacity. Efforts to synergize between ecology, economy and social are the main focus in the framework of fisheries sustainability (Zulbainarni, 2019).

The development objectives are to improve people's welfare and reduce the welfare gap among social groups and regions. However, hitherto, such welfare has not yet been undergone by the majority of society (Solihin et al. 2016). Indonesia's fisheries provide economic profit; however, it is not yet evenly perceived by the fishery actors. This shown the structure of capture fisheries that are still dominated by small scale fishermen. From the development of tuna commodity, it contributes a great value to the national capture fisheries production; however, the IUU fishing problem poses a major threat to its sustainability. The tuna catch, which is mostly produced by small-scale fishermen, is a challenge to the sustainability of tuna small-scales due to competition between small-scale and industrial-scale business actors (Kusdiantoro, 2019).

The development of capture fisheries overlooks many obstacles. These constraints include the condition of the decrease of fish resource availability, where some areas of Indonesia's waters have experienced the symptoms of overfishing. Then, there is still widespread fishing activities by foreign fishing vessels and other forms of violations that are classified as IUU-fishing. Meanwhile, the efforts to conduct fishing efforts in the high seas (high sea) are limited as a result of the ability of the fishing fleet owned by Indonesian fishermen (BAPPENAS, 2014).

The development of partnerships and the empowerment of fishing communities is a way to ensure the sustainability of business and employment in the fisheries sector. In addition to increasing income, developing partnerships and empowering fishing communities can also support the economic and social improvement of the wider population. In addition, the development of partnerships and the empowerment of fishermen is needed to reduce the poverty of fishermen, remove the dependence of fishermen on traditional capital institutions, and as a means to achieve more equitable and sustainable development (Asiasti et al. 2016).

The root cause analysis (RCA) is a structured investigation that aims to identify the real cause of a problem and actions necessary to eliminate it. RCA incorporates a broad range of approaches, tools, and techniques to uncover the cause of the problem, ranging from standard problem-solving paradigms, business process improvement, benchmarking and continuous improvement (Wangen et al. 2017). Based on Irawati et al. 2019, Causes of consideration based on the RCA method for mercury are 1) mercury pollution in the environment as a result of industrial waste using mercury and 2) monitoring of mercury content in UPI is inadequate. Published due to histamine content are: 1) management of tuna in primary production as well as knowledge of fishermen and workers related to inadequate sanitation and hygiene, and 2) cold chains are not maintained since from up to UPI.

The development of capture fisheries is not optimal amid the large of Indonesia fisheries resources. We argue this occurs due to the low ability of the fishing fleet, the existence of IUU fishing, and the role of the 
government. The government policy is required to create the sustainability of fisheries business. The policy is expected comprehensive so that it is not sacrificing stakeholders from upstream to downstream. Therefore, mapping the current fisheries problems is expected to have a sustainable fisheries business policy.

This research mapped the problems in developing the potential of a sustainable capture fisheries sector to realize the development of responsible and ecologically sustainable capture fisheries. This research is expected to be an ingredient in developing a policy on the sustainability of capture fisheries in Indonesia

\section{METHODS}

The method that used in this study is a descriptive method. The descriptive research method aims to gather detailed actual information describing existing indications and identifying problems or examining prevailing conditions and practices so as to provide useful information.

The data that used in this study are secondary data, where the data obtained from the Ministry of Maritime Affairs and Fisheries. In addition, data was collected through a literature study on marine and fisheries studies beforehand and Focus Discussion Group (FGD) as well as depth interviews with fisheries and government multi-stakeholders to collect and map national fisheries problems.

The data in this study were analyzed qualitatively by using national fisheries data and analysis of FGD results. The results of the study were then analyzed using root cause analysis to get the root problem in the current fisheries policy. The root cause analysis (RCA) method is a basic mapping of problems using a causal chain in which problems are arranged or traced based on the cause of the problem until the root problem is obtained. RCA is simply the application of a series of well known, common sense technique which can produce a systematic, quantified, and documented approach to the identification, understanding, and resolution of the underlying cause. The RCA method consists of five stages, such as (Vorley, 2008): Identification of the problem (This stage clearly defines the problem of what is happening at this time and then explains the symptoms specifically that indicate the occurrence of the problem); Data analysis (In this stage, an in-depth analysis must be done before you step in to see the factors that play a role in the emergence of the problem); Cause and effect mapping (is done using "the five why's". This method asks five questions that are used to explore the causes of the relationship that underlies the problem); Identification of the root cause (If the analyst exceeds his capacity in dealing with the root cause, the analyst finally identifies a number of facts in the community to overcome them. The root cause will usually be a factor at the systemic, managerial, procedural, funding, awareness or cultural level); Recommendations/implementations (namely verifying that the root cause is from the root cause. At this stages, it is ascertained whether the corrective steps taken are appropriate to manage the root cause of the problem or instead raise additional problems).

\section{RESULTS}

The amount of capture fisheries resources in Indonesia has not been followed by the contribution of fisheries to the national economy. The contribution of Indonesia fisheries is currently only 3-4\% of GDP in 2018 (Figure 1). Some other countries such as Japan, Korea, China, and New Zealand contribute $30 \%$ of GDP even though geographically, Indonesia has a larger water area. The high potential of Indonesian waters is based to make marine and fisheries as the main sector in Indonesia to increase state revenues.

The potential value of capture fisheries is still much higher than the actual value of fisheries. This is because of government policy constraints, namely the moratorium policy, transshipment, prohibition of fishing gear policies, and others. Some of these policies are listed on the DJPT SE No B1234 / 2015 Max 150 GT Vessel Size Limits, Presidential Regulation No. 44 of 2016 (DNI Public Listed Company), PP No 75 of 2015 - PHP, Minister of Marine Affairs and Fisheries Regulation Number 57 of 2014 - Transhipment Prohibition and slow process management of SIPI / SIKPI.

Based on Figure 2, there is a large difference (gap) between potential and actual utilization so that the current utilization can actually be increased to the level of Total Allowable Catch (TAC) according to the current regulations. At TAC, the allowable catch value is set at $80 \%$ of the Maximum Sustainable Yield (MSY). In detail, the gap is presented in Table 1. 


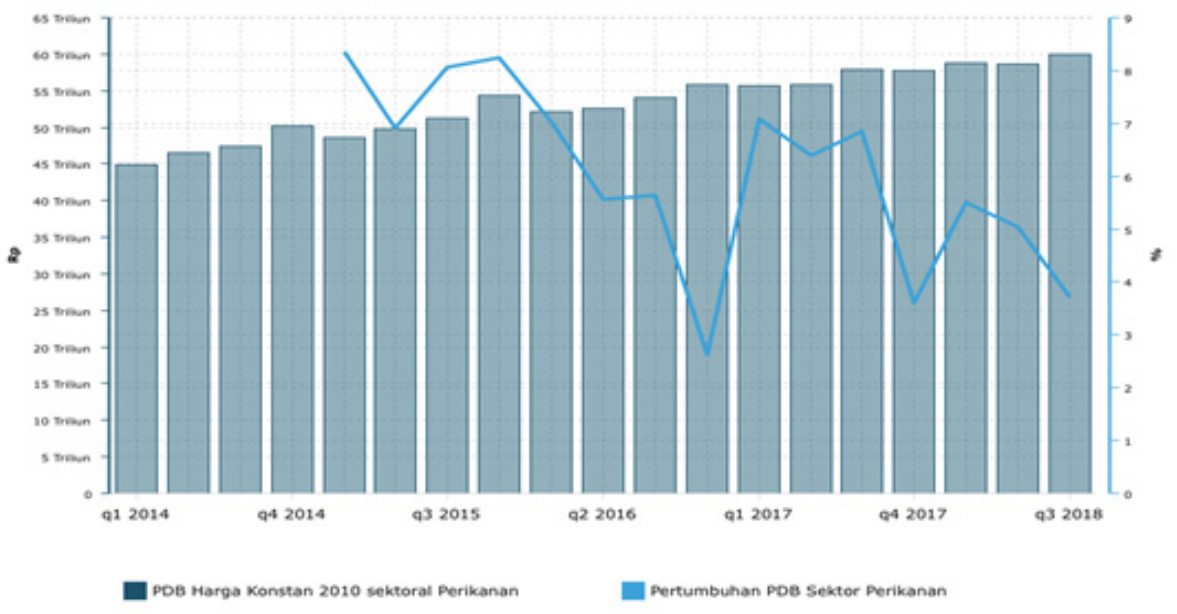

Figure 1. Growth of GDP and GDP in fisheries sector (Triwulan 12014 - Triwulan 3) 2018 (BPS, 2019)

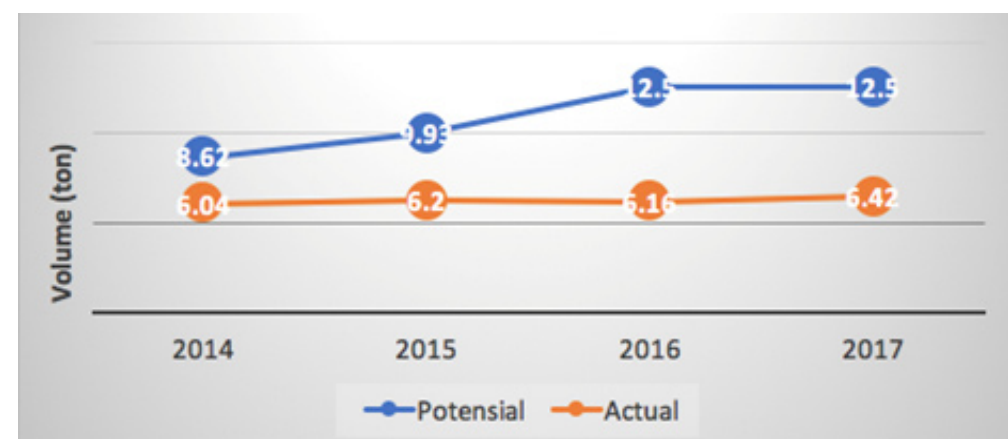

Figure 2. Comparison of capture fisheries potential and actual production 2014-2017

Table 1. Gap between potential and actual capture year 2014-2017

\begin{tabular}{ccccc}
\hline Year & Potential (million ton) & TAC (million ton) & Actual Capture (million ton) & Difference (TAC-Act ) (million ton) \\
\hline 2014 & 8.62 & 6.90 & 6.04 & 0.86 \\
2015 & 9.93 & 7.94 & 6.20 & 1.74 \\
2016 & 12.50 & 10.00 & 6.16 & 3.84 \\
2017 & $12.50^{*}$ & 10.00 & 6.42 & 3.58 \\
\hline
\end{tabular}

*TTC not included

Based on Table 1, it is still possible to increase the use of fishing; this is supported by the issuance of Presidential Instruction (Inpres) Number 7 of 2016 on the Acceleration of the National Fisheries Industry Development which applied since 22 August 2016, Presidential Regulation (Perpres) Number 3 of 2017 on Acceleration of the National Fisheries Industry Development Action Plan. In addition, it is necessary to deregulate and accelerate the licensing and optimization of the Indonesian Exclusive Economic Zone (ZEEI) and the Open Sea.
In the management of the Marine and Fisheries Sector, it cannot be seen partially because the conditions of Indonesian fisheries are as follows: The various size of the vessel (GT); Fishing gears (multi gear: pole and line, long line, longline tuna, purse seine, etc.); Fishing area ( 4 miles, 12 miles, $>12$ miles and $>200$ miles); Catch fish species (multi-species: large Pelagic, small pelagic, demersal, shrimp, squid, crab); Prices of fish are different per species (for example the price of Yellow Fin Tuna and Big Eye Cakalang and others). 
Fisheries management that is still oriented to single species, or focus on economically important fishes, of course, becomes less good for the sustainability of fisheries resources itself because the characteristics of multispecies tropical Indonesian waters are different from other subtropical countries which are single species. Therefore, the optimization of multi-species fisheries tools in Indonesia is important for sustainable and responsible fisheries management.

Fisheries management by region has been stipulated in Minister of Marine Affairs and Fisheries Regulation Number. 01/MEN/2009 regarding the Fisheries Management Area Republic of Indonesia (WPP RI) (Figure 3). With this management, local governments and the central government can focus on developing fisheries resources in certain regions. In Figure, it can be seen that the largest production of WPP 712 in the Java Sea has capture fisheries production that is larger than other regions. This is due to the high number of residents and fishermen in the area. While WPP 717 Cederawasih Bay and the Pacific Ocean is having the lowest production. The imbalance in the amount of production is due to limited fisheries technology so that it cannot reach other areas in Indonesia. In addition, WPP-based management has not been maximized yet.
Small scale fishery businesses often face the risk of losing the value that they catches could theoretically provide. Such monetary values are based on environmental values since small-scale fisheries usually-ly practice selective fishing. If small scale fishers sell their catches in the same channels as trawlers, the risk for the small fishery sector is that the environmental or social value related to the process will not be visible to the buyer. Cooperation is a strategy that can help to overcome the challenges of individual sales for small-scale fishers. This kind of relationship implies important social exchange focusing on information on neglected fish species or offering recipes for the fish sold (Searles et al. 2018).

Based on the explanation, it is known that Indonesia's current fisheries problem is the potential to capture fisheries that have not been utilized optimally. For this reason, the root cause of the issue is analyzed by using the Root Cause Analysis (RCA) method. The following are the root causes of the capture fisheries potential that have not been utilized optimally.

In the root cause scheme Figure 4 the potential of capture fisheries that have not been utilized optimally is caused by unsupportive fisheries policies, single species oriented fisheries management, not yet exploited ZEE and WPP and complicated fisheries management. These problems are caused by several issues.

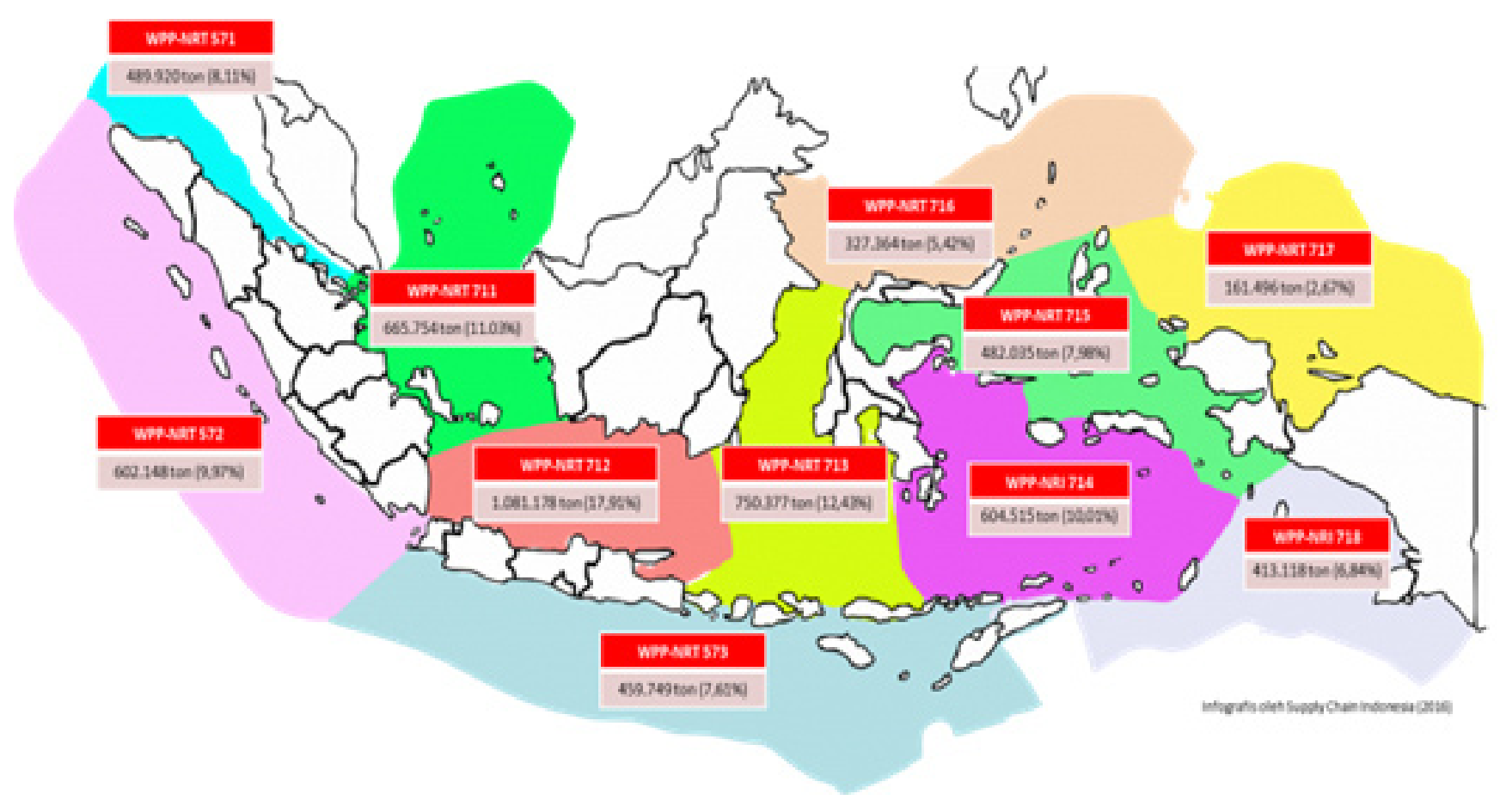

Figure 3. Capture fisheries production fisheries management area Republic of Indonesia (WPP RI) Year 2014 


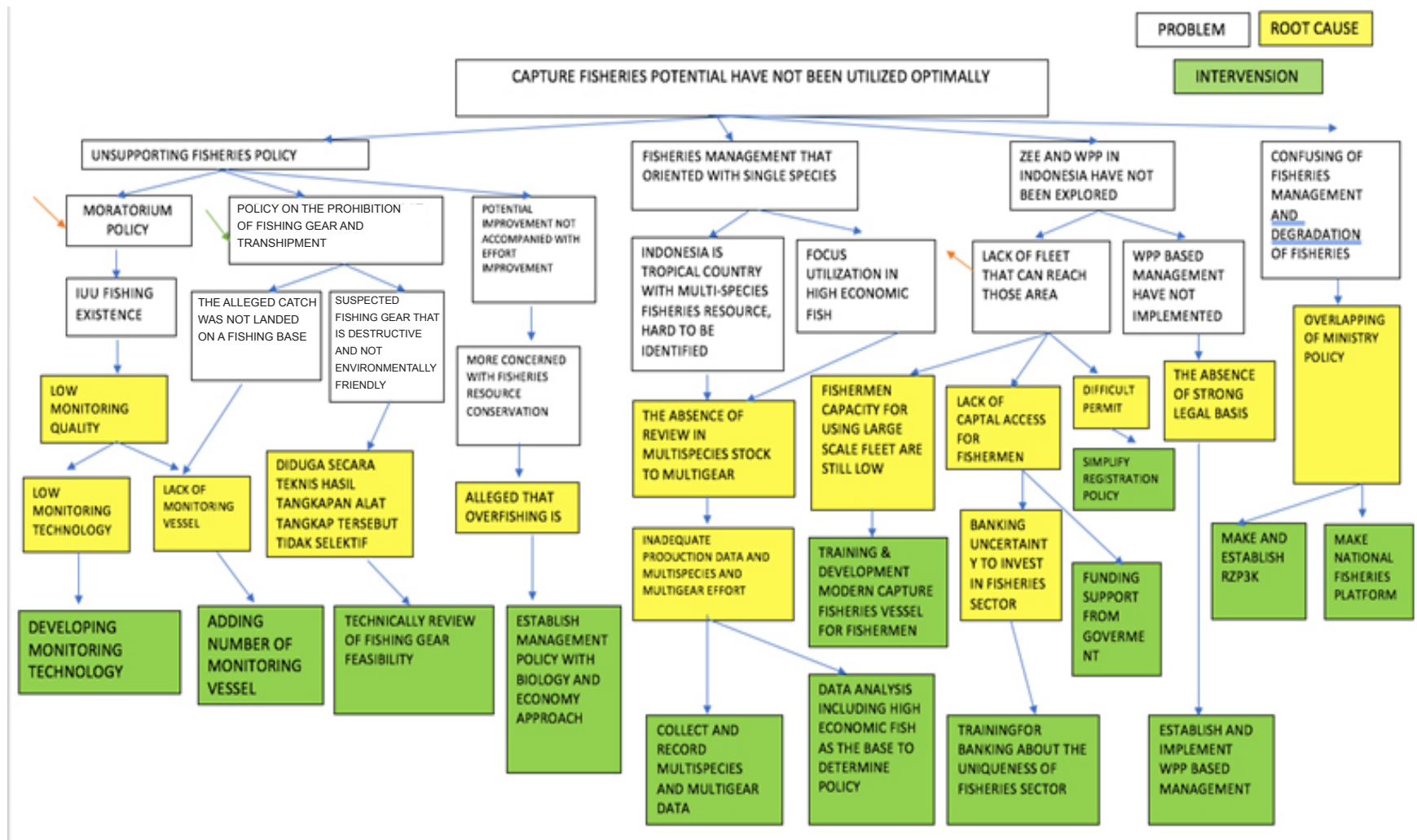

Figure 4. Root problems of capture fisheries potential that have not been utilized optimally

Fisheries policy issues that are not supportive are caused by the moratorium on fishing gear that issued in Minister of Marine Affairs and Fisheries Regulation Number. 5 of 2015 on Prohibition on the Use of Trawling and Seine Nets in the Fisheries Management Areas Republic of Indonesia and vessel moratorium 30 GT and ex-foreign vessel. In essence, the existence of IUU fishing and destructive fishing are based on weak fisheries supervision. Low supervision technology and the limited number of fisheries monitoring vessels is the main cause of IUU fishing and destructive fishing.

Fisheries monitoring vessels play a role in suppressing state losses due to the illegal use of marine and fishery resources, especially that carried out by foreign fishing vessels, as well as the enforcement of Indonesian state sovereignty in the management of marine and fisheries resources. Currently, there are 35 units of fisheries monitoring vessels, which are divided into 17 vessels for the western region and 18 vessels for the eastern region. This amount is still low, considering the Indonesian waters area. At least 45 fisheries monitoring vessels are needed. In addition to monitoring vessels, it is necessary to develop fisheries monitoring technology so that fisheries monitoring is more qualified (DG PSDKP, 2019)(Table 2).
The policy of fishing gear prohibition and restrictions on transshipment are based on the alleged that fish caught is not landed in fishing bases, and fishing gears are alleged to be damaging and not environmentally friendly. On the other hand, the transshipment vessel makes it easier for fishermen to maintain the quality of fish. Fishermen with large pelagic fish catches have a long operational time per trip while cooling technology is not qualified yet. The existence of transshipment vessels can save fuel costs for fishing vessels because they do not need to go to fishing bases and can maintain the quality of fish. The policy of fishing gear and transshipment vessels prohibiting needs to be reviewed because basically, they can provide great benefits that can prosper fishermen.

Increasing the potential of fisheries is not accompanied by an increase in fishing efforts based on current policies that focus more on conservation so that fisheries resources are not utilized optimally. Allegations of overfishing in Indonesian waters have triggered the policy. Based on Indonesian fisheries production in WPP (Figure 16), there are still many areas with potential for fisheries that have not been optimized, especially in the eastern regions of Indonesia, namely WPP 714, 716, and 717. It is necessary to conduct a study of fisheries resource management with a biological and economical 
approach so that the ecological and fishermen business sustainability can be achieved. The model of fisheries Bioeconomics Management is a model of fisheries management by synergi, the biological and economic aspects. Indonesian water conditions that are rich in biodiversity cause bioeconomic orientation of the single species to be modified into multi-species bioeconomics. Multispecies bioeconomic models are formed models that are oriented to many species because fisheries management especially in Indonesia is a composite or multi-Species. Studies of a single species cannot provide scientific of medium-term and long-term management of multi-species fisheries resources (Zulbairnani, 2016).

The next problem with fisheries management is the single species oriented based management on Indonesian fisheries still refers to the stock valuation of sub-tropical countries. The characteristics of multispecies and multigear tropical waters are considered not appropriate with the application of a single species approach. But the next problem is inadequate production data and multispecies and multi-gears capture efforts. The recording of multispecies and multi-gear production data is only spread in some regencies/cities in Indonesia due to the lack of the number and capability of Fisheries Human Resources. For human resources of Fisheries Statistics in the Agency of Marine and Fisheries Makassar City, for example, there is only one person. Whereas the complete recording of production and multispecies and multi-gear fisheries efforts will facilitate fisheries studies. It is necessary to record multispecies and multigear fisheries data accurately so that measurements of fisheries stocks can approach the actual stock value. In addition, fisheries management in Indonesia focuses on high-economic fish so that complete fisheries data related to the catch of fishing gear is required so that other fish can be maximized in the market.
Indonesia gets benefits because it has sovereign rights in the Exclusive Economic Zone (EEZ). This waters region is rich in large pelagic fish resources such as tuna, skipjack, and tongkol. However, currently, the zone has not been optimally exploited because of the limited number of Indonesian fishing vessels that can reach the area. Lack of capital access is the main reason where fishermen need a larger vessel size, and more modern fishing gear to be able to carry out activities optimally in the region. Difficult capital access for fishermen is caused by high-income uncertainty in the fisheries sector, so investors or banks worry that credit payments will not run smoothly. Even though currently there are community business loans (KUR) held by all banks in Indonesia, at present, the banking sector is still difficult to provide funding for fishermen due to the high uncertainty of fisheries income. Even though the fisheries sector is a sector that promises big profits. Training for banks related to the uniqueness of the fisheries sector is required so that banks understand the operations and cash flows of fishermen households.

In addition to EEZ, the untapped area is the Indonesian fisheries management area (WPP). At present, there has been a division of WPP in Indonesia based on the characteristics of biodiversity, ecology, and territorial waters. WPP began to be stipulated in Minister of Marine Affairs and Fisheries Regulation Number. 01/ MEN/2009 on Fisheries Management Areas of the Republic of Indonesia (WPP RI). The area is intended for fishing, aquaculture of conservation research, and fisheries development. Distribution of WPP RI is divided into 11 management areas. At present WPP-based management has not been implemented maximally. There is no strong legal basis for the WPP region, and the division of capture areas based on WPP become evidence of WPP-based management not running optimally. It is necessary to stipulate clear management law in WPP RI so that the WPP-based management can be maximized.

Table 2. The need of fisheries monitoring vessel in each WPP - NRI (unit)

\begin{tabular}{|c|c|c|c|c|c|c|c|c|c|c|c|c|}
\hline \multirow{2}{*}{ Class of vessel (Unit) } & \multicolumn{11}{|c|}{ WPP - NRI } & \multirow{2}{*}{ Amount } \\
\hline & 571 & 572 & 573 & 711 & 712 & 713 & 714 & 715 & 716 & 717 & 718 & \\
\hline A & & & 2 & & & & & & 1 & 2 & 2 & 7 \\
\hline B & & 7 & 3 & 4 & & & 2 & 1 & 2 & & & 19 \\
\hline $\mathrm{C}$ & & & & 2 & & 4 & 4 & 4 & & 1 & & 15 \\
\hline $\mathrm{D}$ & 4 & & & & 10 & & & & & & & 14 \\
\hline \multicolumn{12}{|c|}{ Total of Required Vessel } & 45 \\
\hline
\end{tabular}

Source: Ditjen PSDKP, 2019 
Complex fisheries management is currently an obstacle for fishermen operations. The length of the licensing procedure and overlapping policies by several ministries such as the Ministry of Maritime Affairs and Fisheries, the Ministry of Environment and the Ministry of Tourism has made it difficult for the number of capture fishing fleets to increase. RZP3K and national fisheries platform designation and determination are required.

Based on the description of fisheries problems in the untapped fisheries potential, identified root problems from these problems are: Low quality of supervision, Low of supervision technology, Lack of monitoring vessel, It is assumed that technically the catch of the fishing gear is not effective, There is an alleged of overfishing, The absence of multispecies stock to multi gear studies, The absence of sufficient production and effort data, Low capacity of fishermen using largescale fleets, Lack of capital access, Banking uncertainty about investing in the fisheries sector, Difficult permits, No legal basis for WPP-based management, and Overlapping of technical ministry policies.

Therefore, based on the analysis results of the root problems of potential fisheries that have not been utilized, the recommendations and implementation of the potential of national fisheries that have not been utilized optimally are: Develop monitoring technology, Increase the number of monitoring vessels, Monitoring the feasibility of fishing gear, Establish management policies with biological and economic approaches, Collect and record multispecies and multi gear data, Training and development of modern fishing vessels for fishermen, Analyzing multispecies and multi gear data including economical high fish as a basis for determining policy, Training for banking on the uniqueness of the Fisheries Sector, Capital assistance from the government, Simplify registration policy, Establish laws and implement WPP-based management, Make and establish RZP3K, Create a national fisheries platform

\section{Managerial Implication}

Based on the study of fisheries capture development, the development is require considering the ecological and the business aspects so it is expected the fisheries capture activities will be sustainable. In the ecological aspect, the development of capture fisheries in the form of modernization of fishing gear and the development of skills such as fishing gear assistance and the promotion of environmentally friendly fishing gear will have a positive impact on fishermen in terms of operational knowledge of environmentally friendly fishing gear. It is expected that the fish caught by fishermen are the size of fish that are already feasible to catch. In the business aspect, the amount of catch will increase the profit of the business however it must consider the carrying capacity of the waters. The fishing activities need to be regulated so that fishing does not exceed water capacity. In addition, it need added value through fish processing.

\section{CONCLUSIONS AND RECOMMENDATIONS}

\section{Conclusions}

The development of sustainable capture fisheries sector will have a positive impact to Indonesia's business development. Based on the results of root cause analysis, it is obtained policy recommendations to realize sustainable fisheries in Indonesia, such (1) Develop monitoring technology, (2) increasing the number of monitoring vessels, (3) Monitoring the feasibility of fishing gear, (4) Establish management policies with biological and economic approaches (5) collecting and recording multispecies and multigear data, (6) training and development of modern fishing gear vessels for fishermen, (7) analyzing multispesies and multigear data including high economical fish as basis for determining policy, (8) training for banks on the uniqueness of the fisheries sector (9) capital assistance from the government, (10) simplified registration policies, (11) establishing laws and implementing WPP-based management, (12) Making and establishing RZP3K, and (13) Create a national fisheries platform.

\section{Recommendations}

The capture fisheries is able to support Indonesian economy if it is managed properly. Capture fisheries is a sector that involves many stakeholders so that policy making should be able to consider stakeholders from upstream to downstream. The suggestions for capture fisheries development is the policies need to be supported by government support such as forming a fisheries platform that serves as a mediator for stakeholders so that the policies made subsequently will have a positive impact for stakeholders from upstream to downstream. 


\section{REFERENCES}

Asiati D, Nawawi. 2016. Kemitraan di sektor perikanan tangkap: strategi untuk kelangsungan usaha dan pekerjaan. Jurnal Kependudukan Indonesia 11(2). 103-118. https://doi.org/10.14203/jki. v11i2.204.

[BAPPENAS] Badan Perencanaan Pembangunan Nasional. 2014. Kajian Strategi Pengelolaan Perikanan Berkelanjutan. Jakarta: Direktorat Kelautan dan Perikanan Kementerian PPN/ BAPPENAS.

[BAPPENAS] Badan Perencanaan Pembangunan Nasional. 2014. Kajian Strategi Pengelolaan Perikanan Berkelanjutan. Jakarta: Direktorat Kelautan dan Perikanan Kementerian PPN/ BAPPENAS.

[BPS] Badan Pusat Statistik 2018. Laporan Perikanan Triwulan 2018. Jakarta: Badan Pusat Statistik.

[FAO] Food \& Agriculture Organization. (2018). Fishery and Aquaculture Statistics 2016. Roma: FAO.

Irawati H, Kusnandar F. Kusumaningrum H D. 2019. Analisis penyebab penolakan produk perikanan indonesia oleh uni eropa periode 2007-2017 dengan pendekatan root cause analysis. Jurnal Standarisasi 21 (2): 149 - 160. https://doi. org/10.31153/js.v21i2.757.

[KKP] Kementerian Kelautan dan Perikanan. 2019. Grand Design Kebutuhan Kapal Pengawas Perikanan. Direktorat Pemantauan Dan Operasi Armada. Jakarta: Ditjen PSDKP Kementerian Kelautan dan Perikanan.

[KKP] Kementerian Kelautan dan Perikanan. 2018. Refleksi dan Outlook 2018-2019 Kementerian Kelautan dan Perikanan. Jakarta: Kementerian Kelautan dan Perikanan.

[KKP] Kementerian Kelautan dan Perikanan. 2015. Kelautan dan Perikanan Dalam Angka Tahun
2015. Jakarta: Pusat Data Statistik dan Informasi Kementerian Kelautan dan Perikanan.

[KKP] Kementerian Kelautan dan Perikanan. 2018. Produktivitas Perikanan Indonesia. Jakarta: Kementerian Kelautan dan Perikanan.

Kusdiantoro et al. 2019. Perikanan tangkap di indonesia: potret dan tantangan keberlanjutan. Jurnal Sosial Ekonomi Kelautan dan Perikanan 14 (2) 145162. https://doi.org/10.15578/jsekp.v14i2.8056.

Searls K et al. 2018. Business Strategies in Fish Farming and Small-Scale Fishery. Italy. Conference: 7 th AIEAA Conference " Evidence - based policies to face new challenges for agri - food systems. Hlm 1-16.

Solihin I et al. 2016. The problem and capture fisheries development strategy in border area (case study: Nunukan Regency, Indonesia). Jurnal $A A C L$ Bioflux 9(6): 1310 - 1322.

Suman A et al. 2016. Potensi dan tingkat pemanfaatan sumber daya ikan di Wilayah Pengelolaan Perikanan Negara Republik Indonesia (WPP NRI) tahun 2015 serta opsi pengelolaannya. Jurnal Kebijakan Perikanan Indonesia 8 (2). 97 110. https://doi.org/10.15578/jkpi.8.2.2016.97100.

Vorley G. 2008. Mini Gude to Root Cause Analysis. United Kingdom: Quality Management \& Training (Publications).

Wangen, Gaute B, Hellesen, Niclas, Henrik, Erlend. 2017. An Empirical Study of Root-Cause Analysis in Information Security Management. Rome. Conference SECURWARE, IARIA 2017. Hlm 1 - 14

Zulbainarni N. 2016. Teori dan Praktek Pemodelan Bioekonomi Dalam Pengelolaan Perikanan Tangkap. Bogor: IPB Press.

Zulbainarni N. 2018. Platform Perikanan Nasional Untuk Mencapai SDG's 14. Jakarta: Bappenas. 